\title{
Coronary to pulmonary fistula as the primary source of pulmonary blood supply in pulmonary atresia with ventricular septal defect
}

\section{A case report}

\author{
Isman Firdaus $^{*}$, Cholid T Tjahjono*, Ganesja M Harimurti ${ }^{f}$, Poppy S Roebiono $^{f}$
}

\begin{abstract}
Abstrak
Komunikasi antara arteri koroner dan arteri pulmonalis, yang dikenal sebagai fistula arteri koroner ke pulmonal, merupakan sumber pasokan darah yang sangat jarang ke paru-paru pada penyakit atresia pulmonal yang disertai defek septum ventrikel. Seorang anak perempuan berusia 4 tahun dirujuk ke Pusat Jantung Nasional Harapan Kita dengan gejala dan tanda-tanda peningkatan vaskularisasi pembuluh darah paru sejak bayi dan telah dipastikan dengan pemeriksaan foto X-ray toraks. Pemeriksaan fisik jantung ditemukan bunyi jantung I normal, bunyi jantung II keras dan tunggal, dan didapatkan bising ejeksi sistolik pada area pulmonal. Pemeriksaan EKG menunjukkan irama sinus dengan aksis normal serta hipertrofi biventrikel. Pada pemeriksaan ekhokardiografi dicurigai terdapat trunkus arteriosus tipe I dengan defek septum ventrikel perimembran, overriding aorta, dan dilatasi pada pangkal arteri pulmonalis. Namun demikian pada pemeriksaan kateterisasi jantung ditemukan fistula non obstruktif antara arteri koroner kiri dan pangkal arteri pulmonalis yang disertai kelainan defek septum ventrikel. Tindakan bedah telah berhasil dilakukan sekaligus memastikan diagnosis sebelumnya. Walaupun terdapat episode krisis hipertensi paru selama awal perjalanan pasca operasi, pasien tersebut dipulangkan dari perawatan dengan kondisi yang baik. Karena penyakit pembuluh darah paru yang irreversibel bisa terjadi pada fistula koroner ke pulmonal yang tidak restriktif, pengenalan dini terhadap kelainan ini sangat penting untuk mendapatkan hasil tindakan koreksi bedah yang lebih baik. (Med J Indones 2004; 13: 237-40)
\end{abstract}

\begin{abstract}
A communication between the coronary and pulmonary arteries, so called coronary to pulmonary fistula, is a rare source of pulmonary supply in pulmonary atresia (PA) with ventricular septal defect (VSD). A 4 year old girl referred to National Cardiovascular Center Harapan Kita, Jakarta with symptoms and signs of increased pulmonary blood flow since infancy and was confirmed by the chest $x$-rays. Heart examination revealed normal first heart sound with single loud second heart sound and an ejection systolic murmur at the pulmonary area. ECG demonstrated sinus rhythm with normal axis and biventricular hypertrophy. Echocardiography was performed and truncus arteriosus (TA) type I was suspected with perimembranus VSD, overriding of the aorta, and dilated main pulmonary artery. But on cardiac catheterization studies, a non obstructive fistula was found between the left coronary and main pulmonary artery coexisted with PA and VSD. A successful surgery was performed subsequently and confirmed the above diagnosis. Although there were episodes of pulmonary hypertension crisis during early post operative course, she was then discharge from the hospital in a good condition. Since irreversible pulmonary vascular disease may develop in a non restrictive coronary to pulmonary fistula, early recognition of this anomaly is very important for better surgical result. (Med J Indones 2004; 13: 237-40)
\end{abstract}

Keywords : coronary to pulmonary fistula, pulmonary atresia, ventricular septal defect

The most common sources of pulmonary blood supply in patients with pulmonary atresia are an arterial duct or major systemic-pulmonary collateral arteries. Rarer sources include an aortopulmonary window, persistence of the fifth aortic arch and the

Department of Cardiology and Vascular Medicine, Faculty of Medicine, University of Indonesia, National Cardiovascular Center Harapan Kita, Jakarta coronary to pulmonary fistula. A large fistulous communication arising from the aortic root was described by Krongrad et al as an "aorticopulmonary tunnel." From their description, it is difficult to ascertain whether it originated from a coronary artery, since the coronary arterial anatomy is not described. ${ }^{1,2,3,4}$

Early recognition of the fistulous communications is important, since irreversible pulmonary vascular disease may develop in the lung segments thereby 
supplied if flow is unobstructed. Coronary-pulmonary fistulas should, therefore, be considered as a possible sources of pulmonary blood supply in patients with pulmonary atresia.

\section{Case Illustration}

A girl, 4 years old, came to our hospital with short of breath, feeding difficulty, and failure to thrive since birth. recurrent respiratory tract infection occurred since 3 years old without cyanotic sign. From physical examination, compos mentis, body weight 14 $\mathrm{kg}$, BP 110/54 mmHg, HR $111 \mathrm{bpm}$, and saturation was $88 \%$. Heart examination revealed normal first heart sound with single loud second heart sound and an ejection systolic murmur at the pulmonary area.

Pulmonary hypertension was developed, From ECG finding, there is biventricular hypertrophy with normal axis. Cardiomegali and plethora was confirmed with chest $\mathrm{X}$ ray. She was done echocardiography and diagnosed as truncus arteriousus and VSD perimembranous. From catetherization, we found the fistula that connected the root of the aorta with the main pulmonary artery (MPA), suspected trucus arteriousus. Three weeks later, she underwent surgical operation and we found the left main artery (LM) originated from aortic ascenden pass through the proximal main pulmonary artery then exit distally to the left ventricle, called as coronary to pulmonary fistula. Rastelly procedure was done and LM artery was separated from MPA then VSD was closed.

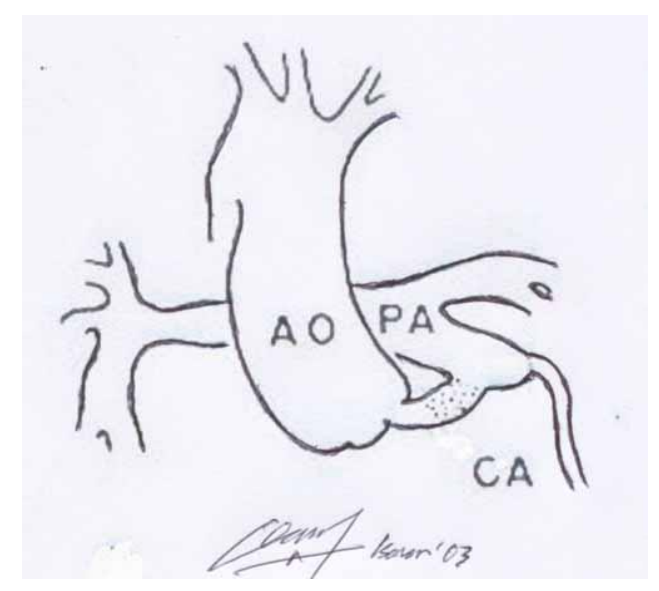

Figure 1. The schematic illustration of Coronary to pulmonary fistula. AO: aorta, PA: Pulmonary artery, CA: coronary artery

\section{DISCUSSION}

The pulmonary blood flow was principally provided by the end-to-side fistula between the left coronary artery and the pulmonary artery. This case had a pathognomonic aorticpulmonary communication consisting of a wide proximal dilated left coronary artery connecting the aortic root to the pulmonary artery. We believe that this typical angiographic picture is diagnostic of pulmonary atresia and coronary artery-to-pulmonary artery fistula.

Our patient had considerable pulmonary blood flow through a fistula between the left coronary artery and main pulmonary artery, as can be seen from the high systemic oxygen saturations. Indeed, operation was advised because of anxiety over possible pulmonary hypertension rather than cyanosis. ${ }^{5}$ The pulmonary artery pressure could not be measured at either catheterization. Although this case described by Krongrad et al had restrictive pulmonary blood flow, our case presented with unrestrictive flow that resulted in pulmonary hypertension.

\section{Frequency}

Anomalous termination of the coronary arteries in the form of a fistulous communication first was reported by Krause in 1865; Abbot subsequently described this condition in 1906. Destinations included the cardiac chambers, the pulmonary artery or vein, bronchial circulation, the coronary sinus, and the vena cavae. In 1971, Oldham compiled almost 200 cases reported in the literature. ${ }^{8}$

Incidence of coronary artey fistula is $0,07-0.2 \%$ of congenital cardiac anomalies. Coronary-pulmonary artery fistula is an extremely rare congenital anomaly of the coronary artery. Its real incidence is unknown. ${ }^{7,8,9}$

In 1978, Wenger reported that coronary artery fistula is found in 1 of every 50,000 patients with congenital heart disease and 1 of every 500 patients who undergo coronary angiography. ${ }^{8}$

Amin et al investigated that coronary to pulmonary collaterals in PA-VSD patient were diagnosed in 9 of 87 patients (10\%).(10) In NCC HK since januaryt 2002-mei 2003, 48 patient with PA/VSD have been operated, 24 patient had source of PA from PDA, 10 patient from MAPCA, 14 patient from other collaterals. 


\section{Embriology}

Pulmonary atresia is characterized anatomically by the absence of any direct continuity between the right ventricle and the pulmonary artery that is no longer embriologically grouped as a variant truncus arteriousus. When the normal connection between the heart and pulmonary arteries is interrupted congenitally the blood supply to the lung is maintain by the ductus arteriousus, bronchial arteries or other systemic to pulmonary collateral arteries such as MAPCA, rarely coronary to pulmonary fistula. ${ }^{11}$

Coronary artery fistula may appear as a persistence of sinusoidal connections between the lumens of the primitive tubular heart that supply myocardial blood flow in the early embryologic period. These channels most often persist when associated with outflow obstruction (eg, pulmonary atresia), yet they also may persist in the absence of obstruction. ${ }^{8}$

\section{DIAGNOSIS}

Most children with coronary fistulae are asymptomatic, and continuous murmur may be audible on routine examinations. In older patients, symptoms may include the following; Dyspnea on exertion, Angina, Fatigue, Palpitations. On clinical examination, the murmur is suggestive of patent ductus arteriosus (PDA) but is heard lower on the sternal border than usual; thus, the location often is atypical for a PDA. In addition, the murmur may have an unusual diastolic accentuation, and the continuous murmur of a coronary artery fistula often peaks in mid-to-late diastole, which is uncharacteristic of the systolic accentuation in a patient with PDA. Some patients with fistulae with a large shunt may present with signs of $\mathrm{CHF}$ and angina. ${ }^{8}$

Two-dimensional echocardiograms may reveal left atrial and left ventricular enlargement as a consequence of significant shunt flow or decreased regional or global dysfunction as a consequence of myocardial ischemia. The feeding coronary artery often appears enlarged, ectatic, and tortuous. Highvolume flow may be detected by color-flow imaging at the origin or along the length of the vessel. Cardiac catheterization remains the modality of choice for defining coronary artery patterns of structure and flow. Most frequently, intracardiac pressures are normal and shunt flow is modest. Aortography or selective coronary arteriography supplies the information required to manage the condition.

\section{Differential Diagnosis}

The differential diagnosis of pulmonary atresia and coronary artery-to-pulmonary artery fistula mainly concerns the 2 other types of ascending aorta-topulmonary communication, namely aorticopulmonary window and truncus arteriosus. In aorticopulmonary window, there is a direct communication, or window, between the ascending aorta and the pulmonary hypertension and dilatation of the pulmonary artery.

In truncus arteriosus, there is absence of a separate main pulmonary artery, absence of a right ventricular infundibulum, and presence of a single truncal valve. Demonstration of a separate main pulmonary artery, a hypoplatic right ventricular infundibulum, or a hypoplastic pulmonary valve excludes the diagnosis of truncus arteriosus. ${ }^{1}$

\section{Surgical consideration}

The repair of this condition involves three steps. First, the coronary artery-pulmonary artery fistula must be closed. In order to avoid dissection of the coronary arteries, particularly the upstream dilated parent vessel with the possible consequent injury or interruption of important branch, we prefer to oversew fistula from within the pulmonary artery. Second, the septal defect is corrected in the usual manner. Third, the pulmonary atresia or stenosis is relieved. For patient in whom the coronary artery-pulmonary artery is too small to provide adequate pulmonary blood flow, and who require surgical aid before the age of 4 or 5 years, we prefer a systemic-to-pulmonary anastomosis (such as blalock anastomosis) and defer the definitive operation until the age of 5 years, or a little older. ${ }^{12}$

The morbidity and mortality rates and late result for correcting this deformity and the long term result currently should be similar to those for the repair of severe tetralogy. ${ }^{12}$

\section{CONCLUSION}

A communication between the coronary and pulmonary arteries, so called coronary to pulmonary fistula, is a rare source of pulmonary supply in pulmonary atresia (PA) with ventricular septal defect (VSD). The differential diagnosis of pulmonary atresia and coronary artery-to-pulmonary artery fistula mainly concerns the 2 other types of ascending aortato-pulmonary communication, namely aorticopulmonary 
window and truncus arteriosus. Since irreversible pulmonary vascular disease may develop in a non restrictive coronary to pulmonary fistula, early recognition of this anomaly is very important for better surgical result.

\section{REFERENCES}

1. Krongrad E, Ritter D, Kincaid O. Aorticopulmonary tunnel : angiographyc recognition of pulmonary atresia and coronary artery-to-pulmonary artery fistula. Am J Roentgenol, 1973,119:498-502

2. Yoo SJ, Moes F, Burrows P, Molossi S, Freedom R. Pulmonary blood supply by a branch from the distal ascending aorta in pulmonary atresia with ventricular septal defect: Differential Diagnosis of Fifth Aortic Arch Pedatr Cardiol, 1993,14;230-3.

3. Wigneswaran W, Pollock J. Pulmonary atresia with ventricular septal defect and coronary artery fistula: a late presentation. Br Heart J, 1988;59:387-8.

4. Elfriede pahl, Lance Fong, Anderson R. Fistulous communications between a solitary coronary artery and the pulmonary arteries as the primary source of pulmonary blood supply in tetralogy of fallot with pulmonary valve atresia. Am J Cardiol. 1989,63: 140-3

5. Pollock. Coronary artery-pulm.artery fistula in TOF with pulmonary atresia. Eur Heart J. 1985;6,714-6

6. Vibhuti N Singh. Congenital Coronary Abnormalities: Surgical Perspective. Medicine Journal, 2003; 4:3.

7. Dervan J, Stephen C, Brook S. Coronary artery-topulmonary artery fistula: A potensial new mechanism. Am. Heart J. 1989,117(4);971-3.

8. Medicine, Andrew N Pelech, MD Coronary Artery FistulaLast Updated: July 18, 2002.

9. Zahid Amin, Doff B. McElhinney, V. Mohan Reddy. Coronary to pulmonary artery collaterals in patients with pulmonary atresia and ventricular septal defect. Ann Thorac Surg 2000;70(1): 119-23.

10. Allen H, Clark E, Gutgesell H. Moss and Adams' Heart Desease in infants, children, and adolescents. 6th ed. 2001.p864-79

11. Krongrad et al. Pulmonary atresia or severe stenosis and coronary artery to pulmonary artery fistula. Circulation. 1972,46;1005-12

12. Atmaca Y. Coronary-pulmonary artery fistula associated with right heart failure. Angiol. 2002,53(5);613-6. 

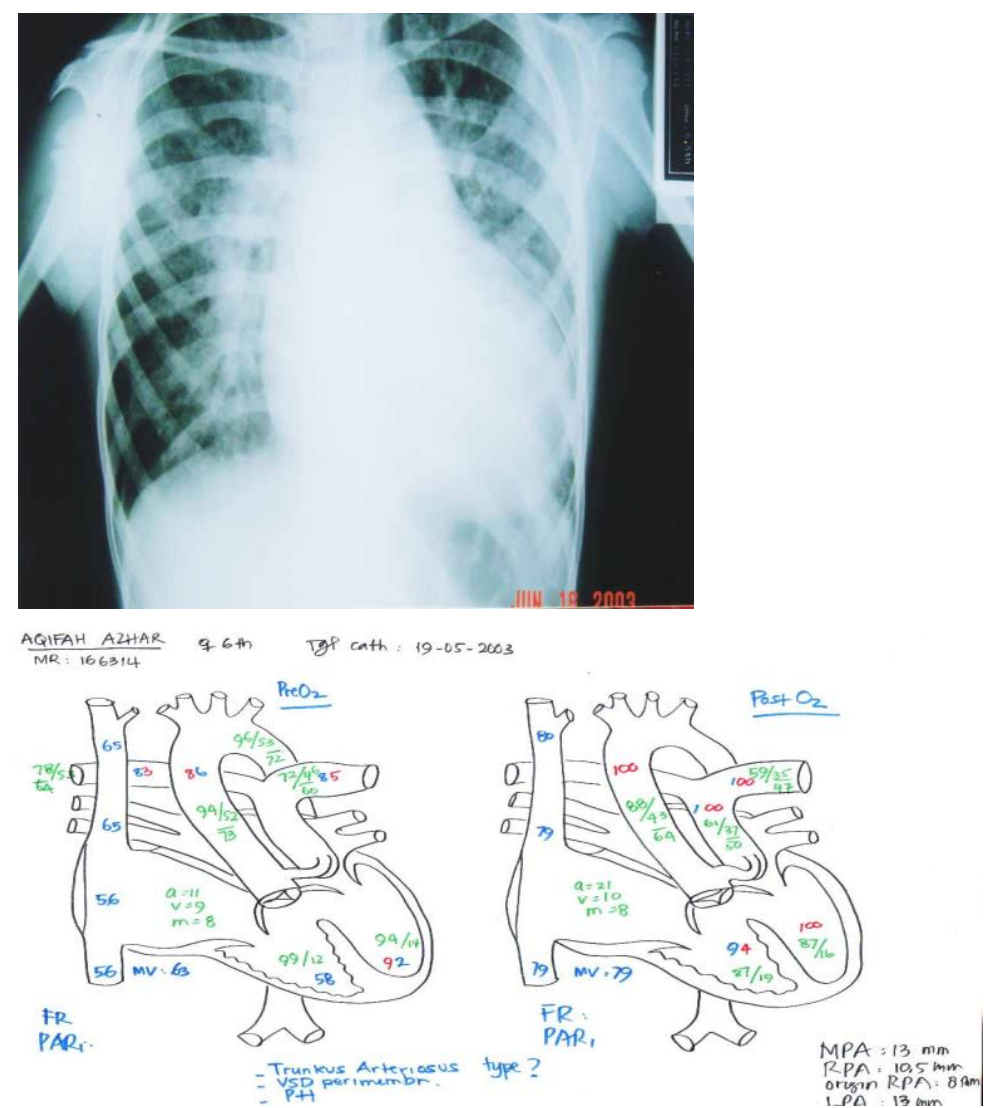


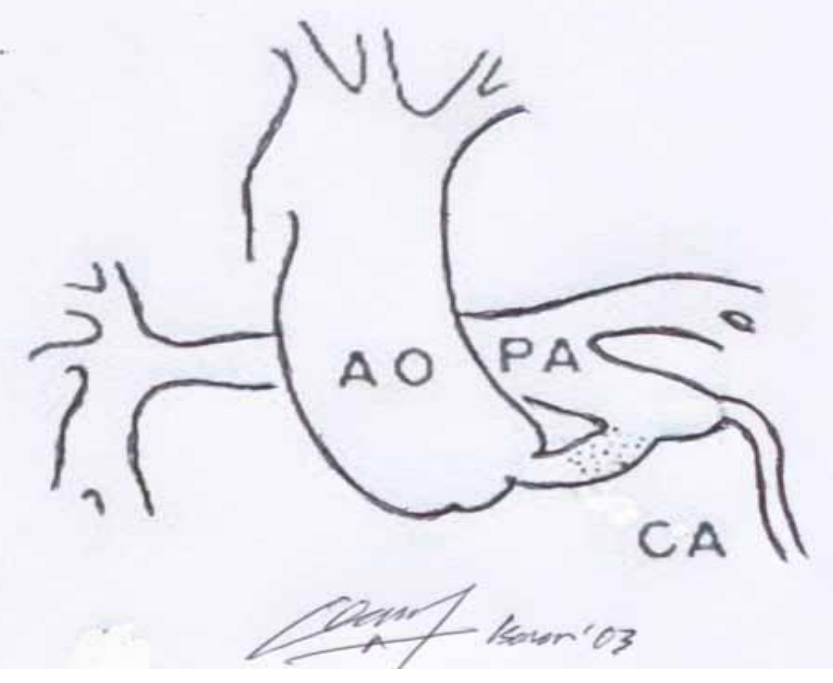

